\title{
Benzene Exposure Analysis through S-Phenylmercapturic Acid in Urine at Platelet Levels in Footwear Workers in Sukajaya Village, Bogor Regency
}

\author{
Siti Norjannah, Ririn Arminsih Wulandari*, Al Asyary \\ Department of Environmental Health, Faculty of Public Health, Universitas Indonesia, Depok, Indonesia
}

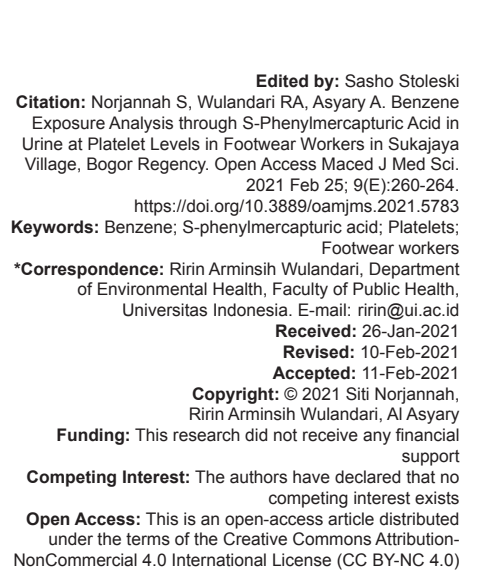

\section{Introduction}

Indonesia has the potential to grow its footwear industry as fashion industry keeps on evolving and as Indonesian population is increasing. In 2012, the Indonesian middle-class population reached 74 million and it is estimated to increase to 141 million by 2020 . This will increase the potential market for the footwear industry [1]. The process of producing footwear includes cutting, gluing, sewing, coloring, and coating. The riskiest activity is the gluing process, as dangerous solvents such as toluene and benzene are present in the glue. Such solvents are toxic and even carcinogenic, so direct contact with humans must be avoided. However, avoidance is not entirely possible in this case [2].

Seventy percent of the total benzene that enters the body is absorbed through respiration, $20-25 \%$ of it through the mouth, and $5 \%$ of it through the skin. A number of disorders are caused by benzene, such as central nervous system disorders and hematological disorders with target spinal cord organs [3]. Determination of benzene exposure in the human body can be done by examining biomarkers of S-phenylmercapturic acid (S-PMA) in urine. S-PMA comes from the condensation of benzene oxide with glutathione and is generally considered to be a very specific benzene biomarker. The average period of S-PMA ranges from 9 to $13 \mathrm{~h}$. The second phase of slow elimination is estimated to be from $1 / 2$ day to around $45 \mathrm{~h}$ [4].

The acute impact of benzene occurs when a person breathes benzene vapor at a high level of 20,000 ppm for $5-10 \mathrm{~min}$. When a person is exposed to benzene for 15-365 days it will affect the central nervous system, causing drowsiness, dizziness, headache, trembling, confusion, and unconsciousness. Chronic effects, such as bone marrow disruption, are caused by exposure to benzene for more than 1 year [3]. Bone marrow disorders affect the production of red blood cells, white blood cells, and platelets. A low platelet count in the human body is called thrombocytopenia, and it can cause skin bleeding or oral mucosal bleeding, impairing the body's ability to maintain homeostasis. However, thrombocytopenia is also found in people with anemia, leukemia, and viral and protozoan infections mediated by the immune system [5], [6].

Bogor Regency has several formal and informal industrial areas. Among the informal industries 
there are home industries, such as footwear, which have a high risk of benzene exposure. One of the areas in Bogor Regency with a significant number of footwear home industries is Sukajaya village. In total, there are 40 footwear home industries employing 350 workers. These small to medium-sized businesses usually pay less attention to the health and safety of their workers and often use dangerous chemicals.

\section{Materials and Methods}

This investigation was a quantitative study with a cross-sectional study design. It was conducted on 73 workers in a footwear workshop in Sukajaya village, Tamansari sub-district, Bogor Regency, West Java Province in March 2018. Characteristic data were collected through interviews, and body mass index (BMI) measurements were also taken. Urine samples were examined by the Health Laboratory of Jakarta using Liquid chromatography-Mass Spectrometry/Mass Spectrometry, and blood sampling and examination were conducted by the Health Laboratory of Bogor using an automated hematology analyzer.

Bivariate analysis was conducted using Chi-square analysis, and multivariate analysis was conducted using logistic regression test variable level between the levels of S-PMA in urine with the platelet levels. The confounding variables in this study were age, total number of years working, daily work duration, BMI, exercise habits, smoking status, and alcohol consumption. The inclusion criteria for study participants were that they must be willing to participate, male, aged 18 years or above, and active workers who have worked for at least 1 year. The exclusion criteria were illness, not being present in the workshop, and having a creatinine level of $<0.3 \mathrm{~g} / \mathrm{dl}$ or more than $3 \mathrm{~g} / \mathrm{dl}$. Ethical approval from The Research and Community Engagement Ethical Committee Faculty of Public Health Universitas Indonesia: 222/H2.F10/PPM.00.02/2018.

\section{Results}

The results of S-PMA concentrations for numerical data showed that the median value was $0.67 \mu \mathrm{g} / \mathrm{g}$ creatinine. The lowest S-PMA concentration was $0.16 \mu \mathrm{g} / \mathrm{g}$ creatinine and the highest S-PMA concentration was $10.245 \mu \mathrm{g} / \mathrm{g}$ creatinine. The S-PMA concentration in categorical data was divided into two groups based on the median value. Those with an S-PMA concentration of $>0.67 \mu \mathrm{g} / \mathrm{g}$ creatinine were put into the High S-PMA concentration group, comprising $31.5 \%$ of the population; those with an S-PMA concentration of $<0.67 \mu \mathrm{g} / \mathrm{g}$ creatinine were placed into the Low S-PMA concentration group, comprising 68.5\% of the population (Table 1).

Table 1: Descriptive Distribution of S-PMA Concentration and Platelet Levels of Workers in Sukajaya Village 2018

\begin{tabular}{|c|c|c|c|c|c|}
\hline Variables & Mean & Median & Standard Deviation & Min-Max & Total $(\%)$ \\
\hline S-PMA Concentration & 1.53 & 0.67 & 2.17 & $0.16-10.245$ & \\
\hline High $(>0.67 \mu \mathrm{g} / \mathrm{g})$ & & & & & 37 (31.5) \\
\hline Low $(<0.67 \mu \mathrm{g} / \mathrm{g})$ & & & & & $36(68.5)$ \\
\hline Platelet Levels & 209.98 & 213 & 31.71 & $140-278$ & \\
\hline$<200 \mathrm{~mm}^{3}$ & & & & & $25(34.2)$ \\
\hline$\geq 200 / \mathrm{mm}^{3}$ & & & & & $(65.8)$ \\
\hline
\end{tabular}

Meanwhile, the results of the blood tests for numerical data showed that the median platelet level was $213 / \mathrm{mm}^{3}$. The lowest platelet level was $140 / \mathrm{mm}^{3}$ and the highest was $278 / \mathrm{mm}^{3}$. Platelet levels in categorical data were also divided into two groups according to Guyton \& Hall (2006), these were $<200 / \mathrm{mm}^{3}$ (34.2\%) and $200-400 / \mathrm{mm}^{3}(65.8 \%)$ (Table 1).

Bivariate analysis was performed to explore the relationship between platelet levels and the independent variables of S-PMA concentration, age, total number of years working, daily work duration, BMI, exercise habits, smoking status, and alcohol consumption. The results showed that the odds ratio (OR) value for S-PMA concentration and platelet levels was 2.28. Workers who had high S-PMA concentrations ( $>0.67 \mu \mathrm{g} / \mathrm{g}$ creatinine) were 2.28 times more at risk of having platelet levels of $<200 / \mathrm{mm}^{3}$ compared to workers who had low S-PMA concentrations $(<0.67 \mu \mathrm{g} / \mathrm{g}$ creatinine) (Table 2).

Table 2: Relationship between S-PMA Concentration and Platelet Levels of Workers in Sukajaya Village, 2018

\begin{tabular}{|c|c|c|c|c|c|c|c|c|}
\hline \multirow[t]{3}{*}{ Variables } & \multicolumn{4}{|c|}{ Platelet levels } & \multicolumn{2}{|c|}{ Total } & \multirow{3}{*}{$\begin{array}{c}\text { OR } \\
(95 \% \mathrm{Cl})\end{array}$} & \multirow[t]{3}{*}{ p-value } \\
\hline & \multicolumn{2}{|c|}{$<200 / \mathrm{mm}^{3}$} & \multicolumn{2}{|c|}{$\geq 200 / \mathrm{mm}^{3}$} & \multirow[b]{2}{*}{$\mathrm{n}$} & \multirow[b]{2}{*}{$\%$} & & \\
\hline & $\mathrm{n}$ & $\%$ & $\mathrm{n}$ & $\%$ & & & & \\
\hline \multicolumn{9}{|c|}{ S-PMA Concentration } \\
\hline High $(>0.67)$ & 16 & 43.2 & 21 & 56.8 & 37 & 100 & 2.28 & 0.163 \\
\hline Low $(<0.67)$ & 9 & 25.0 & 27 & 75.0 & 36 & 100 & $(0.84-6.18)$ & \\
\hline \multicolumn{9}{|l|}{ Age } \\
\hline$>29$ years & 13 & 36.1 & 23 & 63.9 & 36 & 100 & 1.17 & 0.933 \\
\hline $18-29$ years & 12 & 32.4 & 25 & 67.6 & 37 & 100 & $(0.44-3.09)$ & \\
\hline \multicolumn{9}{|c|}{$\begin{array}{l}\text { Total number of years } \\
\text { working }\end{array}$} \\
\hline$>5$ years & 12 & 36.4 & 21 & 63.6 & 33 & 100 & 1.18 & 0.922 \\
\hline $1-5$ years & 13 & 32.5 & 27 & 67.5 & 40 & 100 & $(0.45-3.13)$ & \\
\hline \multicolumn{9}{|l|}{ Daily Work Duration } \\
\hline$>11 \mathrm{~h}$ & 13 & 36.1 & 23 & 63.9 & 36 & 100 & 1.17 & 0.933 \\
\hline$<11 \mathrm{~h}$ & 12 & 32.4 & 25 & 67.6 & 37 & 100 & $(0.447-3.09)$ & \\
\hline \multicolumn{9}{|c|}{ Body mass index (BMI) } \\
\hline Abnormal & 8 & 36.4 & 14 & 63.6 & 22 & 100 & 1.14 & 1.000 \\
\hline Normal & 17 & 33.3 & 34 & 66.7 & 51 & 100 & $(0.40-3.25)$ & \\
\hline \multicolumn{9}{|l|}{ Exercise Habits } \\
\hline Not routine & 19 & 37.3 & 32 & 62.7 & 51 & 100 & 1.58 & 0.578 \\
\hline Routine & 6 & 27.3 & 16 & 72.7 & 22 & 100 & $(0.52-4.74)$ & \\
\hline \multicolumn{9}{|l|}{ Smoking status } \\
\hline Active smoker & 21 & 35.6 & 38 & 64.4 & 59 & 100 & 1.38 & 0.854 \\
\hline Passive smoker & 4 & 28.6 & 10 & 71.4 & 14 & 100 & $(0.38-4.95)$ & \\
\hline \multicolumn{9}{|c|}{ Alcohol Consumption } \\
\hline Yes & 14 & 41.2 & 20 & 58.8 & 34 & 100 & 1.78 & 0.359 \\
\hline No & 11 & 28.2 & 28 & 71.8 & 39 & 100 & $(0.67-4.72)$ & \\
\hline
\end{tabular}

The next variable on platelet count, age, gave an OR value of 1.17 , meaning that workers aged over 29 were 1.17 times more at risk of having platelet levels of $<200 \mathrm{~mm}^{3}$ compared to workers aged 18-29. Meanwhile, the length of work variable on platelet levels gave an OR value of 1.18 . Thus, workers who had worked for more than 5 years had a 1.18 times higher risk of having platelet levels of $<200 / \mathrm{mm}^{3}$ compared to workers who had worked for 5 years or less (Table 2). 
The OR value of the work duration variable for platelet levels was 1.17, implying that workers who worked for more than $11 \mathrm{~h} /$ day had a 1.17 times higher risk of having platelet levels of $<200 / \mathrm{mm}^{3}$ compared to workers who worked for $\leq 11 \mathrm{~h}$. The $\mathrm{BMI}$ variable for platelet levels gave an OR value of 1.14, meaning that workers with abnormal BMI were 1.14 times more at risk of having platelet levels of $<200 / \mathrm{mm}^{3}$ compared to workers who had normal BMI values (Table 2).

Meanwhile, the exercise habit variable on platelet levels gave an OR value of 1.58, meaning workers who did not exercise regularly were 1.58 times more at risk of having platelet levels of $<200 / \mathrm{mm}^{3}$ compared to workers who exercised regularly. The smoking status variable for platelet levels gave an OR value of 1.38 , implying that active smokers were 1.38 times more at risk of having platelet levels of $<200 / \mathrm{mm}^{3}$ compared to secondhand smokers. Furthermore, the alcohol consumption variable for platelet levels gave an OR value of 1.78 . This implies that workers who consumed alcohol were 1.78 times more at risk of having platelet levels of $<200 / \mathrm{mm}^{3}$ compared to workers who did not consume alcohol (Table 2).

From the results of the statistical tests, it can be seen that all variables had a p-value of $>0.05$. Therefore, the variables were excluded one by one from the modeling, starting from the variable with the greatest $p$-value. If the change in OR did not exceed $10 \%$, then the variable was remain released. It was found from the last model that from the variable total number of years working, daily work duration, BMI, exercise habits, and smoking status that were excluded from modeling, the variables that had a change in OR of $>10 \%$ were the age and alcohol consumption variables. These variables were considered to be cofounder variables. Workers who had high S-PMA concentrations (>0.67 $\mu \mathrm{g} / \mathrm{g}$ creatinine) were found to be 2.59 times more at risk of having platelet levels of $<200 / \mathrm{mm}^{3}$ compared to workers whose body contained low S-PMA concentrations $(<0.67 \mu \mathrm{g} / \mathrm{g}$ creatinine) after the age and alcohol consumption variables were controlled for Table 3.

Table 3: Final Model of S-PMA concentration and platelet levels of workers in Sukajaya Village, 2018

\begin{tabular}{llllll}
\hline Variables & Coefficient B & P-value & OR & \multicolumn{2}{c}{$95 \% \mathrm{Cl}$} \\
\cline { 5 - 6 } & & & & Lower & Upper \\
\hline S-PMA concentration & 0.955 & 0.072 & 2.59 & 0.91 & 7.35 \\
Age & 0.334 & 0.522 & 1.39 & 0.50 & 3.87 \\
Alcohol consumption & 0.666 & 0.196 & 1.94 & 0.71 & 5.33 \\
Constanta & -0.296 & 0.582 & 0.74 & & \\
\hline
\end{tabular}

\section{Discussion}

The results in this study were not above the prescribed limits. The American Conference of Governmental Industrial Hygienists (ACGIH) recommends the Biological Exposure Index, which is
$25 \mu \mathrm{g} / \mathrm{g}$ of creatinine in urine. It could be because the results of the measurements of air benzene were below the standard levels of benzene. Because of its volatile and soluble nature, benzene has the potential to pollute the environment and enter the body of workers through inhalation pathways.

Other studies have showed similar results to this one, in which S-PMA concentrations in urine samples were below the prescribed limits. For example, Arrazy's (2016) study on 64 shoe factory workers showed an average S-PMA concentration of $24.63 \mu \mathrm{g} / \mathrm{g}$ creatinine [7]. Meanwhile, the results of a study of 153 bus drivers by Fustinoni et al. (2005) showed a median value of $9 \mu \mathrm{g} / \mathrm{g}$ creatinine, with the lowest value $6 \mu \mathrm{g} / \mathrm{g}$ creatinine and the highest $46 \mu \mathrm{g} / \mathrm{g}$ creatinine. Some samples had high S-PMA concentrations, but only a few because the median value was still far below the ACGIH recommendation [8].

Benzene causes blood problems, and people who breathe benzene for a long time can suffer from harmful effects on the tissues that make up the blood cells, especially the bone marrow. These effects can interfere with normal blood production and cause a decrease in important blood components, which, in turn, can cause excessive bleeding. Excessive exposure to benzene can also harm the immune system, increase infection, and possibly reduce the body's defense against cancer [9]. As blood components, platelets have a role in innate immunity and inflammation, and they have also been shown to have the ability to modulate the adaptive immune response. Furthermore, they have the capacity to store a number of intracellular secret granules which can be released into the circulation or translocated to the surface when activated. Platelets are also capable of producing and releasing large amounts of bioactive proteins and are very important for maintaining body hemostasis [10]. The presence of vascular abnormalities, platelets, coagulation, or fibrinolysis will interfere with vascular system hemostasis, resulting in abnormal bleeding/bleeding disorders.

In their study of 35 carosery industry workers, Mahawati et al. (2006) found no statistically significant relationship between phenol levels in urine and platelet counts. However, they did find that an increase in S-PMA concentration by $1 \mu \mathrm{g} / \mathrm{g}$ creatinine still reduces the platelet count, even if only slightly [11]. Avogbe et al. (2011), meanwhile, studied 144 taxi drivers who were exposed to benzene and found that drivers' platelet levels decreased significantly compared to rural residents who were not exposed by benzene [12].

Other variables can also influence the concentration of S-PMA and the platelet levels of workers. Therefore, it is necessary to examine the effect of multivariate variables on S-PMA concentrations in worker urine and worker platelet levels, because many variables will increase the concentration of S-PMA in urine. These variables include age, length of work, work 
duration, BMI, exercise habits, smoking status, and alcohol consumption. For example, in a study conducted by Marck et al. (2013) on patients at the Red Cross Hospital Burn Center in Beverwijk in the Netherlands it was found that the younger group had significantly higher platelet levels than the older group [13]. Other study, examining 88 male gas station workers, Moro et al. (2015) found that although the risk was the same for every age, the more a person ages, the more the organs in the body weaken, and the greater the decrease in bone marrow productivity. Thus, workers aged over 29 years old must pay more attention to their health and slightly reduce other activities carried out in the workshop when not working [14].

In this study, the variables length of work and work duration were also found to influence platelet levels in workers. In the cohort study, it was found that the longer workers were exposed to benzene, the higher the risk level. Workers who had worked for fewer than 5 years had a 1.0 higher relative risk, while those who had worked 5-9 years had a 1.3 times higher relative risk compared to those who had worked for fewer than 5 years. Workers who had worked for 10-19 years had a 1.6 times higher risk than those who had worked for fewer than 5 years. Finally, workers who had worked for over 20 years had a risk level of 2.7 compared to workers who had worked for fewer than 5 years [15].

The detected benzene concentration was expressed as the inner mean value time for a period of $8 \mathrm{~h}$. Avogbe et al. (2011) found that taxi drivers driving for more than $5 \mathrm{~h}$ a day had increased numbers of antibodies compared to drivers who spend fewer than $5 \mathrm{~h}$ a day driving [12].

In their study of 4352 men at the Tel Aviv Health Center Rejuvenation Survey, Samocha-Bonet et al. (2008) found that there was no significant relationship between BMI and platelet counts. In this study, men with a BMI of $<25$ had an average platelet count of of 241 ( $\times 109 / \mathrm{L})$, men with a BMI of 25-29.9 had an average platelet count of 242 ( $\times 109 / \mathrm{L})$, and men with a BMI of $30-39.9$ had an average platelet count of 246 ( $\times 109 / L)$. Therefore, the higher the BMI of the respondent, the higher the platelet count [16].

In research by Belviranli et al. (2017), it was found that platelet counts increased significantly after exercise. However, they reduced significantly 3-6 h after exercise compared to immediate postexercise values with a $31 \%$ increase in the number of platelets [17]. Therefore, exercise should be done regularly and workers should adopt healthy living habits to be fitter and healthier. In addition to the concentration of S-PMA, many other factors can cause a decrease in platelet levels.

Much needs to be considered in evaluating the biomonitoring of benzene, including both its halflife and metabolism in the body, because everyone has different metabolic rates. Benzene is inhaled not only from the air but also from cigarette smoke, and higher levels of benzene are detected in smokers [4]. Indeed, it is estimated that smokers inhale on average $720 \mu \mathrm{g} /$ day (16 cigarettes/day $\times 45 \mu \mathrm{g} /$ cigarette) of benzene. Smoking has been found to increase platelet activation and trigger a coagulation cascade, which can result in blood clots [18].

Alcohol consumption affects not only platelet production but also platelet function. Thus, patients who consume excessive amounts of alcohol can show a broad spectrum of platelet abnormalities. These disorders include impaired platelet aggregation, decreased secretion or protein activity originating from platelets involved in blood clotting, and prolonged bleeding without thrombocytopenia [19]. The more alcohol consumed, the lower the platelet levels.

Statistically, among all other variables that influenced S-PMA concentration to platelet levels. Age and alcohol consumption variables were confounding variables because the risk of S-PMA concentration on platelet levels is 2.28 (95\% Cl: 0.0.84-6.18), whereas after controlling for the variables of age and alcohol consumption, the risk increases to 2.59 (0.91-7.35). It shows that the elderly societies had care-related challenges in this issue [20].

\section{Conclusions}

After controlling for the variables of age and alcohol consumption, workers with high S-PMA concentrations $(>0.67 \mu \mathrm{g} / \mathrm{g}$ creatinine) were 2.59 times more at risk of having platelet levels of $<200 / \mathrm{mm}^{3}$ compared to workers with low S-PMA concentrations (<0.67 $\mu \mathrm{g} / \mathrm{g}$ creatinine).

Future research could use a cohort study design to examine the extent to which the duration of benzene exposure decreases platelet levels. In terms of wider recommendations, information about the dangers of benzene in glue to health and how to prevent benzene exposure should be disseminated so that workers and companies can take precautions. Creating good quality glue products at affordable prices would also provide a solution.

\section{Author Contributions}

Conceptualization, R.A.W. and S.N.; methodology, R.A.W.; software, S.N.; validation, R.A.W. and S.N.; formal analysis, S.N.; investigation, S.N.; resources, R.A.W.; data curation, S.N.; writing-original draft preparation, R.A.W.; writing-review and editing, 
S.N.; visualization, R.A.W.; supervision, R.A.W.; project administration, R.A.W.; funding acquisition, R.A.W. All authors have read and agreed to the published version of the manuscript.

\section{Acknowledgments}

The author thanks the workers in Sukajaya village as the sample of study.

\section{References}

1. Permana SH. Increasing the National Footwear/Footwear Industry, Bul APBN; 2017. Available from: http://www.berkas. dpr.go.id/puskajianggaran/buletin-apbn/public-file/buletin-apbnpublic-32.pdf. [Last accessed on 2018 Mar 12]. https://doi. org/10.21098/bemp.v13i4.268.

2. Susilowati B. Health Risks to Benzene Exposure to Leather Shoe Industry Workers in Pulogadung PIK in 2011, Thesis. Indonesia: Universitas Indonesia; 2011. Available from: http://www.lib.ui.ac.id/file?file=digital/20288851-s-betty susilowati.pdf. [Last accessed on 2018 Mar 21].

3. Agency for Toxic Substances and Disease Registry. Toxicological Profile for Benzene. Atlanta, GA: Agency for Toxic Substances and Disease Registry; 2007. p. 438. Available from: http://www. atsdr.cdc.gov/toxprofiles/tp3.pdf. [Last accessed on 2018 Apr 01]. https://doi.org/10.4135/9781412963855.n24

4. Arnold SM, Angerer J, Boogaard PJ, Hughes MF, O'Lone RB, Robison $\mathrm{SH}$, et al. The use of biomonitoring data in exposure and human health risk assessment: Benzene case study. Crit Rev Toxicol. 2013;43(2):119-53. Available from: http://www. tandfonline.com. [Last accessed on 2018 Apr 10]. https://doi.org /10.3109/10408444.2012.756455

5. Mehta A, Hoffbrand V. In: Safitri A, Astikawati R, editors. At a Glance Hematologi. Jakarta: Erlangga; 2006.

6. Guyton, Hall JE. In: Irawati, Ramadani D, Indriyani F, editors. Textbook of Medical Physiology. $11^{\text {th }}$ ed. Jakarta: Penerbit Buku Kedokteran EGC; 2006.

7. Arrazy S. Analysis Association S-Phenylmercapturic Acid as Benzene Metabolite with Malondialdehyde Level on Shoe Factory Worker in Centers Shoe Industry Cibaduyut in 2016, Thesis. Indonesia: Universitas Indonesia; 2016. https://doi. org/10.1016/j.cbi.2005.03.031

8. Fustinoni S, Buratti M, Campo L, Colombi A, Consonni D, Pesatori AC, et al. Urinary t, t-muconic acid, S-phenylmercapturic acid and benzene as biomarkers of low benzene exposure. Chem Biol Interact. 2005;153-154:253-6. PMid:15935823

9. ATSDR, Benzene; 2007. Available from: https://www.atsdr.cdc. gov/hec/csem/benzene/docs/benzene.pdf. [Last accessed on 2018 Apr 20].

10. Ferdous F, Scott T. A comparative examination of thrombocyte/ platelet immunity. Immunol Lett. 2015;163(1):32-9.

PMid:25448707

11. Mahawati E, Suhartono S, Nurjazuli N. The correlation between phenol urine concentration, haemoglobin concentration, erythrocyte, thrombocyte and leucocyte (Case study in workers of Carosery Centre industry CV Laksana Semarang). J Kesehat Lingkung. 2006;5(1):45. Available from: https://www.media. neliti.com/media/publications/4834-id-hubungan-antara-kadarfenol-dalam-urin-dengan-kadar-hb-eritrosit-trombosit-dan-I.pdf. [Last accessed on 2018 Apr 05].

12. Avogbe PH, Ayi-fanou L, Cachon B, Chabi N, Debende A Dewaele $\mathrm{D}$, et al. Hematological changes among Beninese motor-bike taxi drivers exposed to benzene by urban air pollution. Afr J Environ Sci Technol. 2011;5(7):464-72. https:// doi.org/10.5539/ep.v2n2p39

13. Marck RE, Montagne HL, Tuinebreijer WE, Breederveld RS Time course of thrombocytes in burn patients and its predictive value for outcome. Burns. 2013;39(4):714-22. https://doi. org/10.1016/j.burns.2013.01.015

PMid:23490002

14. Moro AM, Brucker N, Charão MF, Sauer E, Freitas F, Durgante J, et al. Early hematological and immunological alterations in gasoline station attendants exposed to benzene. Environ Res. 2015;137:349-56. https://doi.org/10.1016/j.envres.2014.11.003 PMid:25601738

15. Dosemeci M, Yin SN, Linet M, Wacholder S, Rothman N, Li GL, et al. Indirect validation of benzene exposure assessment by association with benzene poisoning. Environ Health Perspect. 1996;104 Suppl 6:1343-7. https://doi.org/10.2307/3433188 PMid:9118918

16. Samocha-Bonet D, Justo D, Rogowski O, Saar N, AbuAbeid S, Shenkerman G, et al. Platelet counts and platelet activation markers in obese subjects. Mediators Inflamm. 2008;2008:834153. https://doi.org/10.1155/2008/834153 PMid: 18385810

17. Belviranli M, Okudan N, Kabak B. The effects of acute highintensity interval training on hematological parameters in sedentary subjects. Med Sci (Basel). 2017;5(3):15. https://doi. org/10.3390/medsci5030015 PMid:29099031

18. Pamukcu B, Oflaz H, Onur I, Cimen A, Nisanci Y. Effect of cigarette smoking on platelet aggregation. Clin Appl Thromb Hemost. 2011;17(6):E175-80. https://doi. org/10.1177/1076029610394440

PMid:21406413

19. Oke OT, Samuel O, Adedire OA, Adewuyi IK, Adeyanju OA, Oludayo G. Effect of alcohol consumption on platelets count, intrinsic and extrinsic pathways of blood coagulation. Greener J Med Sci. 2013;3:289-93. https://doi.org/10.15580/ gjms.2013.8.052813643

20. Paplicki M, Susło R, Dopierała K, Drobnik J. Systemic aspects of securing the health safety of the elderly. Family Med Prim Care Rev. 2018;20(3):267-70. https://doi.org/10.5114/ fmpcr.2018.78272 